\title{
Nengsemaken in Surakarta Karaton Karawitan Performance
}

\author{
Joko Daryanto \\ ${ }^{a}$ Universitas Sebelas Maret, Ir Sutami Street 36 A, Surakarta, 57126, Indonesia \\ 1 jokodaryanto@ fkip.uns.ac.id \\ * corresponding author
}

ARTICLE INFO

Article history

Received 2019-03-31

Revised 2019-05-28

Accepted 2019-05-28

Keywords

Karawitan

Karaton Surakarta

Aesthetic Concept

\section{ABSTRACT}

The Surakarta Karaton Karawitan which has lived and developed for centuries in the Javanese culture and its distribution leaves many questions, especially those related to the aesthetic concept of the Surakarta Karaton Karawitan. The description of the Surakarta Karaton Karawitan musical concept as a reference for the Surakarta community has not been widely revealed. This article aims to reveal and describe one of the aesthetic concepts of the Surakarta Karaton Karawitan, namely the concept of nengsemaken. The paradigm of text and context is used to see the Surakarta Karaton Karawitan events as readable sentences or texts. Texts or sentences have tendency with certain meanings that show certain thoughts that ultimately produce meaning. The concept of interpretation of Clifford Geertz was used to read and interpret musical events in the Surakarta Karaton. From the study conducted, nengsemaken was interpreted as tan sora swarané, rempek rampak kabèh mung jinawil, and sajanturing ringgit.

This is an open access article under the CC-BY-SA license.

\section{Introduction}

The Surakarta Karaton was one of the successors of the Mataram Kingdom which broke out due to the agreement of Giyanti (1755), in which the agreement stated that Mataram was divided into two namely Surakarta and Yogyakarta. The agreement was signed on 13 February 1755 (Ricklefs 1995: 149). Javanese gamelan orchestra (known as Karawitan) as one of the important elements in the tradition of karaton life has existed since the reign of Paku Buwana I when the central government was still based in Kartasura. Since then karawitan, it has become an inseparable part of royal activity and life. This is indicated by the presence of karawitan in every ceremony of the karaton tradition.

The presence of karawitan in karaton traditional ceremonies both state and domestic ceremonies shows that karawitan is an inseparable part of karaton activities. This is because the art, as an inseparable part of state activities, is a tradition passed down since Mataram has not separated despite various serious problems faced by Mataram, including the events of the nagari clash (palihan nagari) ${ }^{1}$ which resulted in Mataram breaking into two parts of Surakarta and Yogyakarta and then added the Mangkunegaran Temple where artistic traditions remained a part of royal activity (Fananie 1994: 220).

The Surakarta Karaton Karawitan has been recorded as producing musical works since the reign of Paku Buwana II. We can see the instructions about karawitan activities in the writings of Pradjapangrawit which reported that at that time 17 Javanese songs (gendhing) (Pradjapangrawit 1990: 85-86) had been created for either klenengan ${ }^{2}$ or karawitan dance ${ }^{3}$. It is no exaggeration if the

\footnotetext{
${ }^{1}$ Another term to refer to the outbreak of Mataram into two, namely Surakarta and Yogyakarta

${ }^{2}$ Klenengan is the show of independent karawitan which is not related to other art forms.

${ }^{3}$ Karawitan dance is a show of karawitan for traditional dance music.
} 
Surakarta Palace is considered as a mecca in terms of the stage of karawitan. This is because karaton karawitan presents karawitan with the aesthetic and ethical concepts of the karaton tradition that were in effect hundreds of years ago. Therefore, it is natural that its existence is established, tradition, and even classic (Rustopo 1995: 3).

The aesthetics of the Surakarta Karaton Karawitan in its development became a reference for groups and musicians outside the palace walls. One of the aesthetic concepts of karaton music was expressed by Pradjapangrawit in Serat Sujarah Utawi Riwayatipun Gamelan (Wedhapradangga). Pradjapangrawit described the progress of musical life at that time with the following expression:

"Tetabuhan gangsa alus, thuthukanipun nengsemaken, gendhingipun kathah warni-warni; gendhing kina, gendhing baku karaton, gendhing prenes, gendhing gecul, utawi geculan dalah gendhing manca utawi pasisir inggih kacakup" (Pradjapangrawit 1990:149).

(Gamelan is beaten softly, the sound produced is washed away, lots of gendhing ${ }^{4}$ is mastered, both ancient gendhing, gendhing karaton tradition, gendhing prenes ${ }^{5}$, gendhing gecul $^{6}$, and gendhing from the coastal area.)

The nengsemaken which expressed by Pradjapangrawit has not been elaborated in detail. This article will describe the meaning of the word nengsemaken in the event or performance of the Surakarta Karaton Karawitan.

\section{Method}

This article was written based on the principles of qualitative research methodology, namely (i) describing and explaining; (ii) finding deep information; and (iii) exploring and interpreting. The musical activities of the Surakarta Palace are an art event that can be read as text. Placing art events as text means reading and interpreting events (Ahimsa 2000: 402). The socio-cultural phenomenon in this case is musical performance, which can be seen as a sentence or text that can be read. Sociocultural phenomena as a text or sentence have tendency with certain meanings that indicate certain thoughts that ultimately produce meaning. Interpreting cultural phenomena in the form of compositions, perhaps the concept of interpretation from Clifford Geertz can be borrowed to interpret musical events in the Surakarta Palace. Geertz stated that to analyze culture is not an experimental science to find laws, but an interpretative science to find meanings (Geertz 1992: 5).

\section{Result and Discussion}

The word nengsemaken in Pradjapangrawit's writing can be used as a basis for studying the aesthetic concepts of the karaton karawitan. Nengsemaken according to Bausastra and the Kawi Javanese Dictionary leads to pleasant meanings. Of course, it is necessary to look for things that make a musical performance can be called fun. Three nengsemaken indicators can be seen in the following Figure 1:

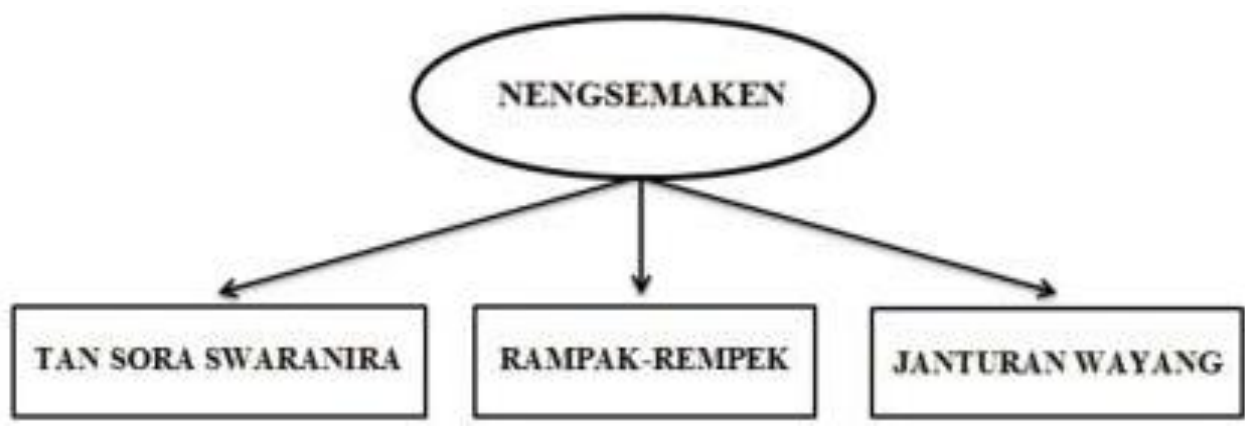

Fig. 1. The Scheme Three Indicators of Nengsemaken

${ }^{4}$ The term to refer to repertoire (= composition) in karawitan.

${ }^{5}$ One atmosphere of feeling in karawitan which describes the atmosphere of joy, pleasure, crispness.

${ }^{6}$ The atmosphere of deep feeling, karawitan which depicts a funny atmosphere, causes the audience to laugh 
The three indicators of nengsemaken are tan sora swaranira, rempek rampak kabèh mung jinawil, sajanturing ringgit. Tan sora swaranira indicates the volume of percussion instrument not more than the size of the instrument dashthat is ukur jawil. ${ }^{7}$ The sound produced from the entire instrument that was beaten was nothing that stood out at all, until the volume of wasps produced a sound that rempek rampak. Prominence of the volume of wasps is only on certain instruments as well as when a puppeteer describes the atmosphere and setting of the scene. In the language of puppetry, it is called janturan. Therefore, it can be called sajanturing ringgit.

\subsection{Tan soraswaranira}

The aesthetics of the Surakarta Karaton Karawitan according to Serat Sri Karongron indicate the results of the not-so-loud volume of wasps, in the Serat Sri Karongron called tan sora swarane. This refers to the alus culture that lives and develops in the Surakarta Karaton. Karawitan is a mainstream element of the Surakarta Palace in forming a form of Javanese culture. Besides, karawitan that lives and develops in the karaton is a color that characterizes the specific values and aura of Javanese culture. Sounds produced from gamelan instruments play a major role in the formation of distinctive cultural atmosphere. Through various types of gamelan instruments and musical compositions, karawitan is able to represent Javanese authority and taste.

Javanese people generally idolize alus $^{8}$ culture as often shown in priyayi life. Priyayi life is always associated with nobles and courtiers (abdi dalem) in the Surakarta Karaton. In the life of the priyayi society, there had been a number of very complex rules until the status of a priyayi was highly respected. Classical Karawitan, which is one of the products of Javanese culture, has a system and rules understood by karawitan society as karawitan laws. It also has alus characteristics. It can be said that karawitan is a reflection of Javanese culture that idolizes alus culture (Waridi 2006: 72).

Karawitan as a manifestation of alus culture thrives and develops in a karaton environment which is considered a source of alus culture. The Surakarta Karaton culture is classified in the alus culture is full of complex symbols. This is what is inherited by the nobles and the people of the Surakarta Palace. It can be said that alus culture which is full of complex symbols is a representation of the mind of the king and the nobles of the Surakarta Palace.

Umar Kayam describes the sentence in krajan gedhe ${ }^{9}$ as the king who sits enthroned becomes the center of the entire cosmos and creates fine artistic and cultural expressions (Kayam 1981: 26). Therefore, it is not surprising that karawitan which is a representation of alus culture lives and develops in karaton because karaton karawitan is a representation of the king's mind, which eventually results in alus culture.

Karaton music as the mainstream of the karaton culture is a reference source for complicated and subtlemusical instruments (ngrawit). This is because the implementation of karaton karawitan is based on the concept of ethics and aesthetic karaton applicable for hundreds of years. Working on complicated karawitan (Javanese = ngrawit) is then maintained, carried out, and developed not only in the palace environment but also among the people. Most people generally assume that karaton culture is understood to have high values and meanings so that it is very feasible to be used as a reference. The laws of karawitan in the form of structure and form, laras, pathet, patterns of wasps that developed in Surakarta Palace until now remain a reference for the karawitan society in general.

\subsection{Rampak-rempek}

The second indicator is rampak rempek in performing gending through the main medium of karawitan. The main medium of karawitan is sound. The medium means that the raw material in the form of sound is used as a tool or means for expressing the experience of the soul or means of expression for the pengrawit (gamelan player) manifested in a gendhing ${ }^{10}$.

These sound elements are processed in such a way as to produce a series of sounds according to the wishes of the pengrawit. These elements are short sound, high-low sound, and color sound. Then the sound sequence will become a rhythmic sound. Rhythm is the most important musical element in

\footnotetext{
${ }^{7}$ Just beaten slowly like poking friends.

${ }^{8}$ Alus $=$ cultured

${ }^{9}$ Umar Kayam term to mention great tradition (kraton)

${ }^{10}$ The term for music composition in the karawitanof Surakarta style tradition
} 
karawitan. In the context of presenting karawitan, a gending performance will not sound well if it is not served with a good rhythm. Gending sounds are categorized as flawed if they are not rhythmic (Javanese = ora irama). Rhythm is the breath of gending, which makes alive (Supanggah 2002: 129).

The Karawitan of the Surakarta style tradition places rhythm as the most important element in a gending performance. In the performance of gending rhythm, it is led by kendang as pamurba irama, which is responsible for regulating the breath of gending while giving life to gending. In carrying out its duties, kendang works in conjunction with the fiddle (rebab) which acts as the yatmaka pamurba or soul leader, the spiritual spirit of gending. Fiddle is the soul of the gending or character of gending, while kendang is more inclined to the aspect of birth or body than gending which concerns the dynamics and sense of gending (Supanggah 2002: 130).

The above paragraph mentions the word pamurba which means leader. The Karawitan tradition of the Surakarta style recognizes two leaders who must work together to create a harmonious gending performance. There is a musical leadership character that is very typical of karawitan so that the character of leadership in karawitan is very different from other musical traditions, especially western music (orchestra). An orchestral concert is led by a conductor who uses visual codes with hand and stick movements.

The musician's attention will be directed at the conductor. In addition to reading the notation, a conductor has the right and obligation to bring the musician to play each instrument to a certain level according to his interpretation of the musical composition character played. In this case the conductor can be said to be the most responsible person orchestral performance so that a conductor has the right to sue every musician to play the instrument that is his responsibility as best as possible according to the conductor's instructions.

Kendang as a leader in karawitan or pamurba irama has a different role with conductors. In leading karawitan performance, kendang plays a role as a pamong or harmonizer. The difference between kendang and a conductor that can be captured visually is that a conductor leads an orchestra from the outside and does not play the instrument, while the leader of the karawitan performance or a kendang player (hereinafter called pengendang) leads the musical performance while playing kendang. With musical idioms in the kendang performance, pengendang leads a karawitan performance while playing in it.

In Javanese, it is known as melu nglakoni or melu ngayahi. Pengendang does not only give the signal as does the conductor. He must give an example of how hard the volume of wasps, how complicated the pattern of wasps, and how fast the tempo is developed. Gradation of the volume, complexity, and speed chosen by the kendang will be followed by other instruments. In this case, it is not justified between one instrument and the other covering each other (Javanese) or sinking the volume of wasps of his partner, especially nyilep kendang. Karawitan tradition does not recognize the protruding self in the performance. Pengendang must be able to lead his colleagues so that there is no volume chaos in karawitan performance.

Pengendang in determining the rhythm must see the ability and level of skill of other horizons. In addition, in leading the gending performance, pengendang is fully responsible during gending performance, the decision to stop, finish, or proceed to the other gending must see the other skill of the composer. The karawitan tradition does not allow pengendang to impose his will. If he is imposing his will, karawitan performance will sound out of harmony.

The harmony of the gending performance is full of responsibility until the gending performance will arrive at the level of rampak and rempek. The two aesthetic terms of karawitan are basic demands or minimum standards that must be fulfilled in karawitan performance. Rampak is an aesthetic demand that is closely related to togetherness in playing together which is related to the element of speed or time. Whereas rempek involves a sense of togetherness in playing together that is related to elements of volume, space, or dynamics (Supanggah 2002: 124).

Rampak and rempek are not just together in volume and speed. In the concept of rampak and rempek there are dynamics presented by each instrument. In western music the dynamics are determined by the personal conductor, so that the success rate of the performance is more determined by the conductor. The dynamics of musical tradition are made by each composer (pengrawit) through playing instruments as his responsibility. The role of pengendang is the 
moderator of musical discussions carried out by his colleagues through his musical codes, rhythm games, selection of beat patterns, and kendang volume. Supanggah stated that pengendang could one day be a musician as well as a playmaker, even as a field general, but he still had to be able to be a moderator, pamomong (caregivers and role models) by playing (ngayahi, nglakoni) while paying attention to the skills, abilities, and skills of the pengrawit. Kendang must also be responsible for the impact and collision of the wasps by looking at the context of the place, function, and time at the performance (Supanggah 2002: 132).

\subsection{Janturan ringgit (puppet)}

The third indicator of the aesthetic concept of the Surakarta Karaton karawitan refers to a part of the Pakeliran ${ }^{11}$ Wayang Purwa performance. Pakeliran wayang purwa Surakarta Style tradition recognizes several parts of the scene to support pakeliran performance, including scenes or sections to describe the setting or atmosphere of the scene. The small parts in a pakeliran performance are joined to realize a dramatic structure in complete pakeliran.

In other words, in the pakeliran performance there is a dramatic structure in a performance of pakeliran. The dramatic structure of the drama pakeliran overnight is a sequence of scenes from the beginning (bedhol kayon) to the end (tanceb kayon) which contains the core story in each scene and is presented in three parts, namely pathet nem, pathet sanga, and pathet manyura. In each pathet there are dramatic elements in the form of catur, jaturan, pocapan, sabet, and karawitan pakeliran which include sulukan and gendhing (Sarwanto 2008: 173).

One part of the dramatic structure of pakeliran is janturan. This section contains a description of the scene, both the atmosphere of the scene and the setting of the scene. The definition of complete distribution is expressed by Sarwanto, who states that spells are mastermind discourses in the form of descriptions of ongoing scene situations. This distribution usually describes the setting, location, atmosphere, greatness and services of figures and interpretations accompanied by illustrations of gendhing sirepan (Sarwanto 2008: 181).

The definition of janturan is revealed by Sarwanto calls gending sirepan. The presentation of sirep gending does not involve all ricikan ${ }^{12}$ in one gamelan instrument. The ricikan involved in performing sirepan gending is ricikan rebab, kendang ageng or kendang sabet, gender barung, slenthem $^{13}$, gong, kenong, and kethuk. The involvement of several ricikan in the gending sirepan shows that in the performance of sirepan gending does not require a loud volume of wasps, but the essence of gending still appears with the emergence of ricikan garap ngajeng group, namely fiddle and gender barung, structural ricikan groups namely kethuk, kenong, kendang, and ricikan balungan ${ }^{14}$ groups represented by slenthem. In general, sirepan gending that is presented already represents a complete form of performance because three groups of ricikan namely ricikan garap, structural ricikan, and ricikan balungan are present in the performance of gending sirepan.

A complete musical performance which is marked by the presence of all the sounds in one gamelan instrument will arrive at the level of nges or karasa ngespun if the sound produced from ricikan which presents gending sirepan is heard or not by the sound produced by another noise. Nges relates to harmony, which is a musical sense that combines elements of karawitan, including the technique of wasp, the pattern of percussion, rhythm and laya, laras, pathet, convention, and dynamics.

\section{Conclusion}

The aesthetic concept of Surakarta Karaton Karawitan is deemed to be interpreted by fulfilling three criteria, namely tan sora swarané, rempek rampak, and sajanturing ringgit in the Surakarta Karaton Karawitan performance. Tan sora swarané refers to the volume of wasps produced; rampak rempek refers to the results of the wasp of each instrument in a gamelan ensemble that does not highlight the sound of one instrument; but all instruments are clearly heard. Sajanturing ringgit refers to the calmness of the atmosphere resulted from the wasp of each instrument.

\footnotetext{
${ }^{11}$ One of the Javanese traditional theater performance, usually called by pedalangan

${ }^{12}$ The synonym of instrument

${ }^{13}$ Some people argue that the presence of slenthem in the singing process is facultative.

${ }^{14}$ Instrument that plays the main melody of the song
} 


\section{References}

Ahimsa, Heddy Shri. 2000. Ketika Orang Jawa Nyeni. Yogyakarta: Galang press.

Fananie, Zainudin. 1994. Pandangan Dunia KGPAA Hamangkoenagoro I Dalam Babad Tutur: Sebuah Restrukturasi Budaya. Surakarta: Muhammadiyah University Press.

Geertz, Clifford. 1992. Tafsir Kebudayaan. Penerbit Kanisius.

Kayam, Umar. 1981. Seni, Tradisi, Masyarakat. Penerbit Sinar Harapan.

Pradjapangrawit, Raden Ngabehi. 1990. Serat Sujarah Utawi Riwayating Gamelan, Wedhapradangga:(serat Saking Gotek). Sekolah Tinggi Seni Indonesia.

Ricklefs. 1995. Sejarah Indonesia Modern. Yogyakarta: Gadjah Mada University Press, Translated from. Penjelidikan dalam Pengukuran.

Rustopo. 1995. "Keberadaan Karawitan Pada Masa Pemerintahan Paku Buwana X Menurut Serat Sri Karongron.” Surakarta.

Sarwanto. 2008. Pertunjukan Wayang Kulit Purwa Dalam Ritual Bersih Desa (Kajian Fungsi Dan Makna). Surakarta: ISI Press.

Supanggah, Rahayu. 2002. Bothekan Karawitan. Masyarakat Pertunjukan Indonesia.

Waridi. 2006. Karawitan Jawa Masa Pemerintahan PB X: Perspektif Historis Dan Teoritis. Surakarta: ISI Press. 